Ars Educandi

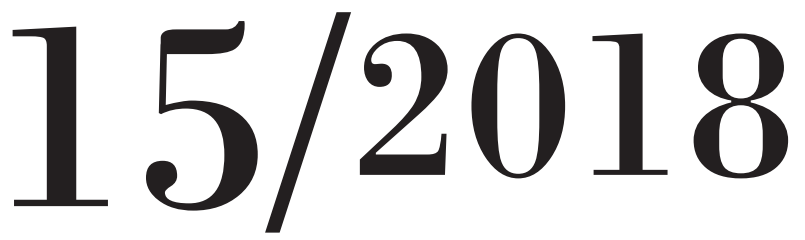

Wydawnictwo

Uniwersytetu Gdańskiego 
Krystyna Rybicka

https://doi.org.10.26881/ae.2018.15.01

Ośrodek Książki Obrazkowej

Miejskiej Biblioteki Publicznej w Lublinie

krystynarybicka@o2.pl

\section{(Nie)obecność książki obrazkowej w strukturach uniwersalnej klasyfikacji dziesiętnej ${ }^{1}$}

\section{Wprowadzenie}

Współczesne odkrycia naukowe wynikające $\mathrm{z}$ analizy pojęć czasu i przestrzeni zmieniły nie tylko wiedzę o świecie, wpłynęły również na społeczną percepcję otaczającej nas rzeczywistości, a także na całe spektrum zjawisk prezentowanych przez sztukę najnowszą, w tym sztukę książki. Jednym z interesujących gatunków stała się książka obrazkowa, określana mianem: ikonotekst, picturebook, picture book. Treści w niej zawarte przechodzące płynnie pomiędzy obrazami i tekstem skupiły się w sposób szczególny na prezentowaniu wymiarów czasu i przestrzeni na płaszczyźnie kart książki. Aby móc opisać tę ważną cechę książki obrazkowej, warto może powrócić do prezentacji zadań literatury oraz sztuk plastycznych Gottholda Ephraima Lessinga, które zawarł w rozprawie Laokoon z 1766 roku (zob. Lessing 2012). Jego rewolucyjne jak na owe czasy poglądy ponownie przeanalizowali Seweryna Wysłouch (1994: 15-38) i Hans Holländer (2006: 188-190). Lessing pisał, że głównym zadaniem malarstwa jest swobodne obrazowanie przestrzeni na płaszczyźnie blejtramu, zatrzymanie jej w kadrze (unieruchomienie w czasie). Wątek akcji możliwy jest wówczas do prześledzenia $\mathrm{w}$ całości, $\mathrm{w}$ jednym obrazie. Literatura natomiast - w przeciwieństwie do malarstwa - opisuje problemy liniowo, w następującej po sobie kolejności, co niesie wprawdzie możliwość swobodnego poruszania się w czasie akcji, odwoływania do przeszłości i przyszłości, jednak pozbawia je przestrzennej równoczesności. W dalszych badaniach punktem

${ }^{1}$ Artykuł jest tekstem referatu, który został wygłoszony 8 grudnia 2017 roku podczas ogólnopolskiej konferencji naukowej „W interakcji słów i obrazów” zorganizowanej przez Instytut Pedagogiki Uniwersytetu Gdańskiego, Pracownię Interdyscyplinarnych Badań Książki Obrazkowej przy Uniwersytecie Gdańskim oraz Nadbałtyckie Centrum Kultury w Gdańsku. 
krytycznym staje się więc moment spotkania i wzajemnego przenikania czasu i przestrzeni zarówno w malarstwie, jak i w literaturze (Wysłouch 1994: 16). Jako spoiwo pomiędzy wymiarami zaproponowano w książce grafikę (z racji wspólnoty warsztatowej z drukiem) współtworzącą w XX wieku poezję konkretną, a także powieść graficzną i książkę obrazkową.

\section{Definicje książki obrazkowej}

Podręczny słownik bibliotekarza (Czapnik, Gruszka 2011:168) konsekwentnie powtarza za Encyklopediq wiedzy o książce (Birkenmajer 1971: 1278):

Książka obrazkowa. Książka zawierająca wyłącznie ilustracje, niekiedy uzupełnione bardzo krótkim, czytelnym tekstem; przeznaczona na ogół dla małych dzieci, analfabetów i osób słabo czytających. Książka obrazkowa może być również wydawnictwem o charakterze rozrywkowym (np. komiks lub album rysunków satyrycznych) adresowanym do szerokiego kręgu odbiorców.

W dobie szczegółowych badań nad fenomenem książki obrazkowej prowadzonych przez pedagogów, literaturoznawców i historyków sztuki definicja ta wydaje się co najmniej zaskakująca. Wystarczy prześledzić przeprowadzone przez Małgorzatę Cackowską w Książce obrazkowej. Wprowadzenie podsumowanie całej gamy definicji książki obrazkowej: Barbary Bader, Perry’ego Nodelmana, Marii Nikolajevej i Carole Scott, Uriego Shulevitza, Kennetha A. Marantza, Kristin Hallberg, Ulli Rhedin, Eliny Druker, Niny Christensen, Jensa Thiele (Cackowska 2017: 11-13), podkreślającej ponadto, że istotą gatunku są różne relacje pomiędzy obrazem i tekstem oraz praca tych dwóch modalności na rzecz jakości książki obrazkowej pojmowanej jako całość. Istotną rolę odgrywa również oferta wydawnicza, bogactwo poligrafii i edy torstwa skłaniających się ku potraktowaniu książki obrazkowej jako obiektu artystycznego (ibidem: 13).

Książki obrazkowe rozróżnia ponadto na te, które stosują zasadę narracyjności, i te, które ją odrzucają, przypominając, że przy zastosowaniu współbrzmienia obrazkowego i językowego kodu brak któregokolwiek sprawia, że sens książki staje się niezrozumiały, a treść niekompletna (ibidem: 21). Za najciekawszą odmianę książki narracyjnej uważa się tzw. postmodernistyczną książkę obrazkową, gdzie słowa i obrazy dostarczają odmiennych bądź przeciwstawnych informacji, czyli znów poprzez ściśle określone funkcje proponują czytelnikowi nowy wymiar treści.

W przytoczonej z podręcznika dla bibliotekarzy definicji cechy budowy książki obrazkowej, będące kluczowe dla tego gatunku, nie pojawiają się niestety wcale. Określenie, że „może być również wydawnictwem o charakterze rozrywkowym”, a krąg odbiorców jest zawężony do „małych dzieci, analfabetów i osób słabo czytających" zmienia wręcz jej przesłanie. Jakie więc przełożenie ma praca krytyków i naukowców związanych z książką obrazkową na pracę 
bibliotekarzy, od których w wielkiej mierze zależy późniejszy los książki i jej kontakt z czytelnikiem?

\section{Sygnatura i miejsce książki obrazkowej w katalogu}

Tożsamość książki potwierdza się w trafnym umiejscowieniu jej na półce bibliotecznej i nadaniu odpowiedniej sygnatury według danych (tytuł, autor, temat, wydawca, data publikacji, format, język, ISBN). Jeden z najpopularniejszych systemów klasyfikacji księgozbiorów nazywany uniwersalną klasyfikacją dziesiętną (UKD) (zob. Uniwersalna klasyfikacja dziesiętna 2006) obowiązujący w bibliotekach publicznych zaznacza wprawdzie obecność szaty graficznej w poddziałach wspólnych formy książki, pozwala sobie jednak jedynie na lakoniczne określenia bogactwo ilustracji (02.025.2) (ibidem: 14) i przedstawienia graficzne (084) (ibidem: 16). Obraz jest traktowany jako charakterystyczny element formalny książki, jej właściwość, pominięte są całkowicie zadania ilustracji jako autonomicznego nośnika treści traktowanego na równi ze słowem, z tekstem.

Jakie więc są kryteria tworzenia owej jednoznacznie brzmiącej sygnatury w przypadku dzieł z pogranicza literatury i sztuk plastycznych, gdzie tekst wybrzmiewa w pełni tylko w sąsiedztwie ilustracji lub jego funkcja jest zaledwie uzupełniająca, podrzędna? Co w takim przypadku buduje strukturę książki - mimo wszystko słowo czy jednak obraz? Czy różnorodne klasyfikacje, decydujące o miejscu mediów na półce bibliotecznej, mające rozbudowany aparat badawczy dostosowany do treści werbalnych, potrafią również jednakowo skutecznie klasyfikować sferę wizualną? Czy dysponują metodami pozwalającymi na porządkowanie, opis formalny i systematyzującą charakterystykę książek zawierających obrazy? Czy bogactwo kontekstów zawarte w koncepcji książki obrazkowej zostało dostrzeżone w strukturach sygnatur bibliotecznych?

Z doświadczeń autorki tekstu i jej wieloletniej pracy w bibliotece publicznej wynika, że kryteria te są niejasne albo wręcz nie istnieją. W tym miejscu warto przedstawić opisy bibliograficzne słynnych narracyjnych książek obrazkowych pojawiających się na polskim rynku wydawniczym². I tak Maurice Sendak, Tam, gdzie żyją dzikie stwory otrzymuje opis „opowiadanie dziecięce amerykańskie 20 wieku”; Babette Cole, Mama zniosta jajko! - „opowiadanie dziecięce angielskie 20 wieku”; Wolf Erlbruch, Gęś, śmierć i tulipan oraz Straszna piątka - „opowiadania dziecięce niemieckie 21 wieku”; natomiast Wielkie pytanie - „książki dla małych dzieci”.

Podkreślana sekwencyjność słowa i obrazu w bibliotecznym haśle przedmiotowym nie pojawia się wcale.

Typ książek narracyjnych operujących wyłącznie obrazami, bez tekstu, otrzymuje opisy: Aleksandra i Daniel Mizielińscy Miasteczko Mamoko - „Literatura

\footnotetext{
${ }^{2}$ Na podstawie danych z katalogu Miejskiej Biblioteki Publicznej w Lublinie, maj 2018.
} 
dziecięca polska 21 wieku. Książka obrazkowa. Książki dla małych dzieci”; ale Rottraut Susanne Berner, Noc na ulicy Czereśniowej już tylko - „Książka dla małych dzieci".

Przy restrykcyjnej konsekwencji budowania haseł przedmiotowych przez bibliotekarzy katalogerów nieustannie zaskakuje swoboda zakresów przytoczonych sformułowań i brak odniesień do szaty graficznej.

W niniejszych spostrzeżeniach zawężonych do funkcjonowania książki obrazkowej w księgozbiorach bibliotek publicznych może warto przypomnieć, że pozycje zawierające krótką treść i bogatą szatę graficzną trafiają generalnie do księgozbiorów dziecięcych - bez względu na wielowarstwowość przesłania. Po prześledzeniu wytycznych Biblioteki Narodowej dotyczących zbiorów dla młodych odbiorców (Lewandowicz-Nosal 2008) okazuje się dodatkowo, że opis odnosi się do treści werbalnych, pomimo dominacji na kartach książki szaty graficznej (abstrakcyjnej lub figuratywnej). I tak definicja „książki-zabawki” brzmi następująco:

Do tego działu należą obecne na rynku wydawniczym pozycje bez tekstu lub zawierające tylko jednowyrazowe lub kilkuzdaniowe podpisy, wszystkie książki zaopatrzone w jakiekolwiek elementy do manipulacji, także wykonane z innych materiałów niż papier. Publikacje te są przeznaczone dla dzieci w wieku 0-5 lat (ibidem: 8).

Trudno doszukać się choćby jednego zdania o ilustracji jako formie budującej treść książki.

Podobnie dzieje się z pojęciem książki wczesnokonceptowej, do której należą słowniki ilustrowane umieszczone w literaturze popularnonaukowej (dział 81, z poddziałem wspólnym języka) (ibidem: 15). Wypowiedzi autorów książek wczesnokonceptowych, edukacja za pomocą obrazów, w opisie bibliograficznym jest zupełnie niewidoczna.

Natomiast komiks zyskujący określenie „narysowane opowiadanie” został wyodrębniony w klasyfikacji bibliotecznej ze względu na „specyficzną formę wypowiedzi artystycznej" (ibidem: 14), ale już nie można się dowiedzieć, w czym leży specyfika tejże wypowiedzi. Może warto jeszcze dodać, że komiksy wchodzą do działu „Literatura masowa. Literatura brukowa. Komiksy” (Uniwersalna klasyfikacja dziesiętna 2006: 284), sygnatura zaś ogranicza się do wyodrębnienia cech literackich.

Miejsce książki obrazkowej na bibliotecznej półce

Opis bibliograficzny i sygnatura książki decydują o jej ustawieniu na półce. W dużych bibliotekach naukowych udostępniane książki, przechowywane najczęściej w magazynach, mogą być ustawiane nawet według kolejnego numeru inwentarzowego, czyli według kolejności zakupu. Natomiast w bibliotekach publicznych $\mathrm{z}$ wolnym dostępem czytelnika do półek książki wchodzą między sobą we 
wzajemne relacje, budują nowe konteksty. Przemyślane sąsiedztwo książek wzbogaca je nawzajem, pomaga przeprowadzać kwerendy, proponować w zamian inne książki zamiast oczekiwanej, pokazywać różnorodność tematu, którym zainteresował się czytelnik. Albo wręcz przeciwnie - przypadkowo skatalogowana książka przepada, gubi swoją tożsamość, zmniejsza się jej szansa na konstruktywny kontakt z czytelnikiem. I tak właśnie książki obrazkowe rozproszone po różnych działach biblioteki tracą wiele na swoim potencjale estetycznym i edukacyjnym. Wystarczy prześledzić ponownie opisy i idące za tym ustawienia na półkach bibliotecznych autorskich książek (o uniwersalnym przesłaniu) choćby jednej z najbardziej znanych twórczyń polskiej książki obrazkowej - Iwony Chmielewskiej. Umieszczone są w „opowiadaniach polskich 21 wieku” albo „miniaturach literackich”, przedział wiekowy 6-8 lat: Cztery zwykłe miski; Kłopot; Pamiętnik Blumki; Maum: dom duszy (hasło „Dusza”); Oczy (hasło „Niewidomi”). W następnym przedziale wiekowym 9-10 lat, również jako „opowiadania polskie 21 wieku”: Dwoje ludzi; Cztery strony czasu. Jedynie Królestwo dziewczynki zakwalifikowane jest jako „Pokwitanie. Książka obrazkowa. Opowiadanie polskie 21 wieku”, choć do niedawna jeszcze przypisane było do w działu „Medycyna” dla dzieci w wieku 11-14 lat. Przy czym nie sposób jednoznacznie odpowiedzieć, dlaczego tylko Królestwo dziewczynki otrzymało określenie „książka obrazkowa” a inne książki tejże autorki już nie?

Z kolei leporello Marka Bieńczyka i Joanny Concejo Książę w cukierni jest „opowiadaniem dziecięcym polskim 21 wieku” w przedziale wiekowym 9-10 lat.

\section{Podsumowanie}

Niejasne kryteria opisów zawartych w strukturach klasyfikacji UKD dotyczących treści wizualnych książek obrazkowych powoduje, że wyszukiwanie ich w katalogu i na półkach bibliotecznych nasuwa wiele wątpliwości. Tekst, postrzegany na równi z obrazem, przepojony intencją pobudzenia zmysłów wzroku lub dotyku niełatwo daje się wdrożyć w tradycyjny układ księgozbioru. Jeżeli jednak książki z oryginalną szatą graficzną, współtworzącą jej treść na równi z tekstem albo nawet dominującą nad tekstem, wydzieli się z działu „Literatura” („8”) i postawi bliżej działu „Sztuka” („7”), dokładniej „Grafika” („76”), wymowa wybranych książek stanie się czytelniejsza i pojawi się możliwość ustawiania ich na półce, uwzględniając w pierwszej kolejności nazwisko projektanta, a w drugiej autora tekstu. Powstaje nowy zbiór, kolekcja książek z oryginalnym alfabetem wizualnym, znakiem czasu, przemian socjologicznych, poligraficznych, historycznych. Dzielenie książek ze względu na wiek odbiorcy - często niepotrzebny - przestaje być priorytetowy, książki eksponują cechy niezależnego, pięknego obiektu. Potwierdza się idea książki - dzieła sztuki - zawarta na wystawie i w publikacji Polska Szkoła Książi Obrazkowej (Cackowska, Wincencjusz-Patyna 2017). Otwiera przed czytelnikiem panoramę informacji o artystycznym rodowodzie książki, o jej ścisłych związkach z grafiką, 
plakatem, w końcu o jej twórcach, treściach książki ukrytych w kompozycji kart książek i rozkładówek.

Jorge Luis Borges w 1941 roku w Mar del Plata napisał wizjonerskie opowiadanie o Bibliotece Babel, o totalnym zbiorze zapomnianej wiedzy zapisanej według „kombinacji dwudziestu kilku symboli ortograficznych strzeżonej przez grupę oddanych, skazanych na wyginięcie bibliotekarzy" (zob. Borges 1972: 65-73). Przy czym w prezentacji przestrzeni labiryntów uporządkowanego chaosu wiedzy dawał nadzieję czytelnikowi na rozpoznanie zawiłej struktury wszechświata. Opowiadanie powstało na kilkanaście lat przed objęciem przez Borgesa stanowiska dyrektora Biblioteki Narodowej w Buenos Aires i przed globalną cyfryzacją zasobów bibliotecznych na świecie. Przewidział załamanie procesu archiwizacji i porządkowania wiedzy wyłącznie za pośrednictwem kodu słów?

\section{Literatura}

Birkenmajer A. (red.), 1971, Encyklopedia wiedzy o książce, Wrocław: Zakład Narodowy im. Ossolińskich.

Borges J.L., 1972, Fikcje, tłum. K. Piekarec, Warszawa: Państwowy Instytut Wydawniczy.

Cackowska M., 2017, Wspótczesna ksiażka obrazkowa - pojęcie, typologia, badania, teorie, konteksty, dyskursy [w:] Książka obrazkowa. Wprowadzenie, red. M. Cackowska, H. Dymel-Trzebiatowska, J. Szyłak, Poznań: Instytut Kultury Popularnej.

Cackowska M., Wincencjusz-Patyna A., 2017, Polska Szkoła Książki Obrazkowej, proj. i oprac. graf. G. Lange, Gdańsk: Nadbałtyckie Centrum Kultury.

Czapnik G., Gruszka Z., 2011, Podręczny stownik bibliotekarza, Warszawa: Wydawnictwo Stowarzyszenia Bibliotekarzy Polskich.

Holländer H., 2006, Literatura - malarstwo - grafika [w:] Ut pictura poesis, red. M. Skwara, S. Wysłouch, Gdańsk: Wydawnictwo słowo/obraz terytoria.

Lessing G.E., 2012, Laokoon czyli o granicach malarstwa i poezji, oprac. M. Mencfel, tłum. H. Zymon-Dębicki, Kraków: Universitas.

Lewandowicz-Nosal G (oprac.), 2008, Wykaz działów katalogu rzeczowego w bibliotekach publicznych dla dzieci i młodzieży, Warszawa: Biblioteka Narodowa.

Uniwersalna klasyfikacja dziesiętna. Wydanie skrócone dla bieżacej bibliografii narodowej i bibliotek publicznych. Publikacja nr UDC-P058 autoryzowana przez Konsorcjum UKD nr licencji-2005/06, 2006, tablice oprac. T. Turowska, J. Hys, J. Kwiatkowska, Warszawa: Biblioteka Narodowa.

Wysłouch S., 1994, Ut pictura poesis, czyli o malarskości literatury [w:] idem, Literatura a sztuki wizualne, Warszawa: PWN.

Materiały źródłowe

Berner R.S., 2013, Noc na ulicy Czereśniowej, Warszawa: Wydawnictwo Dwie Siostry. Bieńczyk M., Concejo J., 2013, Książę w cukierni, Wrocław: Wydawnictwo Format. Chmielewska I., 2011, Pamiętnik Blumki, Poznań: Media Rodzina. 
Chmielewska I., 2012, Kłopot, Warszawa: Wydawnictwo Wytwórnia.

Chmielewska I., 2013a, Cztery strony czasu, Poznań: Media Rodzina.

Chmielewska I., 2013b, Cztery zwykłe miski, Wrocław: Wydawnictwo Format.

Chmielewska I., 2014a, Dwoje ludzi, Poznań: Media Rodzina.

Chmielewska I., 2014b, Królestwo dziewczynki, Warszawa: Wydawnictwo Entliczek.

Chmielewska I., 2014c, Oczy, Wrocław: Wrocławskie Wydawnictwo Warstwy-Miejska Biblioteka Publiczna.

Cole B., 2004, Mama zniosła jajko!, tłum. H. Baltyn, Warszawa: Nasza Księgarnia.

Erlbruch W., 2006, Wielkie pytanie, tłum. J. Kutyła. Warszawa: Wydawnictwo Hokus-Pokus.

Erlbruch W., 2007, Straszna piątka, tłum. Ł. Żebrowski, Warszawa: Wydawnictwo Hokus-Pokus.

Erlbruch W., 2008, Gęś, śmierć i tulipan, tłum. Ł. Żebrowski, Warszawa: Wydawnictwo Hokus-Pokus.

Heekyoung K., Chmielewska I., 2016, Maum. Dom duszy, tłum. J. Lee, Wrocław: Wrocławskie Wydawnictwo Warstwy-Wrocławski Dom Literatury.

Kaminski J., 2012, Majn Alef Bejs, tłum. W. Wilczyk na podstawie tłum. filologicznego K. Szymaniak; il. U. Palusińska, Kraków: Żydowskie Stowarzyszenie Czulent.

Mizielińska A., Mizieliński D., 2010, Miasteczko Mamoko, Warszawa: Wydawnictwo Dwie Siostry.

Sendak M., 2014, Tam, gdzie żyja dzikie stwory, tłum. J. Jędryas, Warszawa: Wydawnictwo Dwie Siostry.

\section{Streszczenie}

Książki obrazkowe oraz te ciekawie zilustrowane, wyeksponowane w bibliotece jako dzieło sztuki, transponowane na różne nośniki (książka, grafika, aplikacja, rozwiązania multimedialne), wskazują czytelnikowi obecność nowych, unikatowych wartości zbiorów, wzbudzają zainteresowanie w każdym przedziale wiekowym, stają się międzypokoleniowym pomostem, zachęcają do utrwalania nawyku czytania. Ponadto, jeśli zakres usług oferowanych przez bibliotekę obejmuje bezpośredni i przyjazny kontakt $\mathrm{z}$ autorami książek ilustratorami, pisarzami - podczas wernisaży i warsztatów może stać się przełomowym momentem zarówno dla czytelników, jak i bibliotekarzy, zachęcając ich do zapoznania się z historią epoki i szerokich kontekstów kulturowych.

\section{Słowa kluczowe}

książka obrazkowa, biblioteka, katalog 


\section{Summary \\ The (non)presence of picturebook in the structures \\ of the Universal Decimal Classification}

Picture books, as well as the ones interestingly illustrated, exhibited as works of art in various media (a book, graphics, an application, multimedia solutions), draw attention of readers to the new and unique values of library collections, arouse interest among all age groups, become an intergenerational bridge, encourage and enhance the reading habit. Moreover, if a range of services offered by a library includes a direct and friendly contact with book authors - illustrators, writers - during vernissages and workshops, it can become a breakthrough moment, both for readers and librarians, encouraging them to become familiar with history of the epoch and wide cultural contexts.

Keywords

picturebook, library, catalog 